International Journal of Linguistics, Literature and Translation

ISSN: 2617-0299 (Online); ISSN: 2708-0099 (Print)

DOI: $10.32996 /$ ijltt

Journal Homepage: www.al-kindipublisher.com/index.php/ijllt

IJLLT

\title{
Challenges of Teaching English Listening, Speaking, Reading and Writing Skills at Qawmi Madrasas under BEFAQ in Bangladesh
}

\author{
Md Abdul Karim Ruman 8 (D) \\ Lecturer, Department of English, College of Sciences \& Arts in Al-Namas, University of Bisha, Saudi Arabia; and Ph.D. \\ Researcher (English language), Institute of Modern Languages, University of Dhaka, Bangladesh.
}

$\Delta$ Corresponding Author: Md Abdul Karim Ruman, E-mail: rumanphd@gmail.com

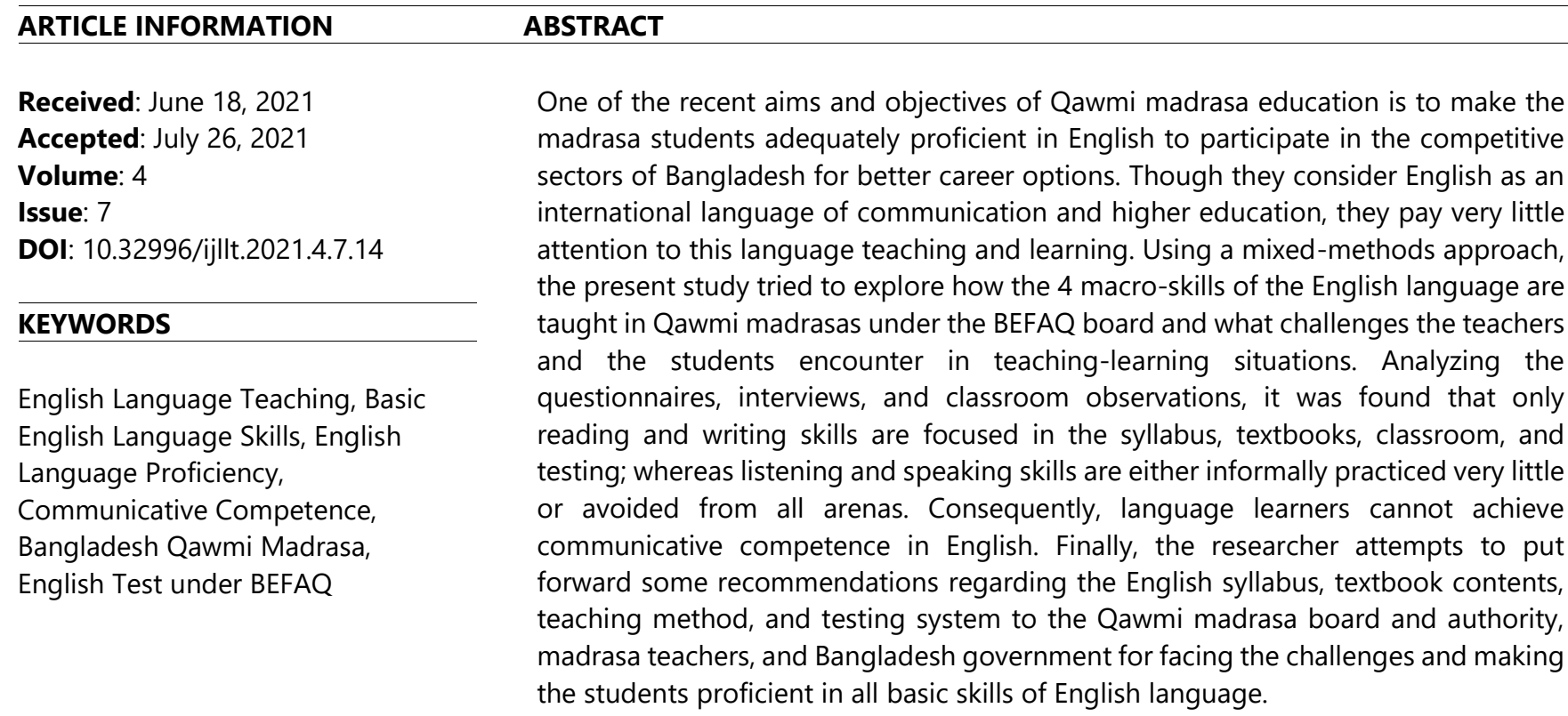

\section{Introduction}

In order to be able to communicate internationally in the current age of globalization, people need to acquire the fundamental skills of the English language: listening, speaking, reading, and writing. English is taught as a compulsory subject in all streams of education in Bangladesh. But macro-skill focused language teaching is a major challenge for most of them, e.g. Qawmi madrasa. Qawmi madrasa is a dimension where Islamic education is provided (in Arabic, Urdu, and Farsi languages) with some secular courses, such as English, Bengali, Math, History, Geography \& Social Studies, etc. Since English as a foreign language is taught here as an optional course besides Farsi, this subject is given less importance either by the students or the teachers, or both. Even though both English and Farsi are taught simultaneously, a great majority of the students attend the final test on Farsi. Some students also learn English just for passing the examination. As a result, they cannot achieve proficiency in all basic skills of the English language in spite of studying for a couple of years.

\subsection{Background of the Study}

By the medium of instruction, the education system in Bangladesh can be categorized into three streams: Bengali medium, English medium, and Islamic faith-based or madrasa education. The madrasa education has two further streams-Aliya and Qawmi (Barkat et al., 2011, p. 36; Asadullah \& Chaudhury, 2016, p. 57). Qawmi madrasa was evolved in the Indian subcontinent more than 150 years ago by the conservative part of the Muslim community as a rejection of the British education policy (Hussain, 2018). This stream of education does not follow government-approved curricula and mainly offers religious education such as memorizing the Quran and analysis of the Quran and Hadiths (Barkat et al., 2011, p. 36; Bhattacharya, 2006, p. 227). As a matter of fact, until April

K C AL-KINDI CENTER

$R$ DFOR RESEARCH AND DEVELOPMENT

Your gateway to world-class research

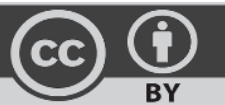

Published by Al-Kindi Center for Research and Development, London, United Kingdom. Copyright (c) the author(s). This open access article is distributed under a Creative Commons Attribution (CC-BY) 4.0 license 
2017 the graduate degree offered by such madrasas was not recognized by the Bangladesh government. Referring to a report prepared by Bangladesh Bereau of Educational Information and Statistics (BANBEIS), a leading national daily said that 73,731 teachers are teaching a total of 1.4 million students in 13,902 Qawmi madrasas across Bangladesh (Ahmed, 2015). Again, studies report 19 different private independent boards for governing these Qawmi madrasas and Befaqul Madarishil Arabia Bangladesh (BEFAQ) is the largest among them (Asadullah \& Chaudhury, 2016, p. 57). The current study deals with this education board which has been teaching (grade I-VIII) and testing (grade V) English since the academic year of 1987-1988. Since BEFAQ conducts the final examination of English only in grade $V$, this study will focus on the teaching and learning of the basic English language skills at this level.

\subsection{Statement of the Problem}

According to the analysis of language teaching proposed by Richards and Rodgers (1982), "method"—a prescription for how language can best be taught and learned-is the cover term for all of the language teaching, from theory to practice. In other words, each method or approach has an articulated theoretical orientation and a collection of strategies and learning activities designed to reach the specified goals and achieve the learning outcomes of the teaching and learning processes. In Qawmi madrasas under BEFAQ, the traditional Grammar-Translation method is adopted in ELT classrooms, where students are expected to understand and memorize the lists of English vocabulary, grammar rules, etc. to translate selected text and prepare for their test (Ruman \& Bhuiyan, 2015). According to Richards and Schmidt, Grammar-Translation is "a method of foreign or second language teaching which makes use of translation and grammar study as the main teaching and learning activities" (2002, p. 231). This method advocates translation into and from the target language. Here, the medium of instruction is the learner's mother tongue. Besides, reading and writing are the major focuses, whereas speaking and listening are paid almost no attention in this method (Richards \& Rodgers, 2001). So, there are scopes for the learners to lose communicative competence. In other words, this leaves the Qawmi madrasa students to lack some basic English language skills. They cannot use the English language in real contexts. They might know grammar rules but do not know how to frame sentences while speaking in English. Indeed, they never receive proper exposure to all the skills of TL as they cannot take an interactive part in the learning situations. Being passive receivers, the learners lack a proper direction to achieve their goal of acquiring English language proficiency. This study will explore the challenges encountered by them in the process of acquiring listening, speaking, reading, and writing skills of English.

\subsection{Research Objectives}

The study aims to address the following research question:

How are the macro skills of the English language, i.e. listening, speaking, reading, and writing taught in the Qawmi madrasas under BEFAQ board of Bangladesh?

But before that, it is necessary to know-Why is the English language taught in this stream of education?-which will be explored first.

\subsection{Goals and Objectives of the English Syllabus in Qawmi Madrasa Curriculum}

The main goal and objective of the English Syllabus in the Qawmi madrasa curriculum is to make the madrasa students adequately proficient in English, so that they may participate equally in the competitive sectors with the students of general education and English medium education streams since English has become a significant language for international communication and higher education, and better career options in Bangladesh (National Education Policy 2010, p.18). In other words, the main aim is to promote an age-related 'communicative competence', which means to be able to use the English language in real-life situations. To cite Farooqui in this regard, "Developing communicative language ability is the global goal of current English language education" (2014, p. 441). However, a closer look at the lessons of the English textbooks taught in Class $\checkmark$ of Qawmi madrasas reveals the following organizing principles: some macro-skills (reading and writing) and micro-skills like grammar and lexicon. Thus, the English textbooks do not include communicative activities (listening and speaking) which were highly required to fulfill the madrasa curricular objective.

\section{Literature Review}

Very few studies have so far been conducted on English language teaching in Qawmi madrasas of Bangladesh. As has already been discussed, the English subject has been introduced in the current Qawmi Madrasa curriculum to meet the requirements of the current global age. However, Al-Hasani, Ismail, Kazeemkayode, and Elega (2017) conducted a study on the practices of Qawmi madrasa in Bangladesh and found that Qawmi authorities do not agree with the government to reform their education to prepare graduates according to the needs of global demand. They also found that Qawmi graduates cannot join in the jobs of private and government sectors due to the lack of modern subjects and curriculum and the absence of current marketbased skills. Here, it is noteworthy that nowadays English language proficiency is a prerequisite for jobs. Editorial of a Bangladeshi daily The Independent on 30 November 2015 can be quoted in this regard: "Most madrasa students believe that by learning Islam, 
they will go to heaven. A similar motivation for learning English or science subjects is absent and they are not convinced that learning those subjects is important."

Azam and Tatsuya (2020) have investigated what improvements need to be made to the English teaching program in Qawmi Madrasas to enable students to successfully apply for positions in the civil service in Bangladesh. The improvements include teacher training for English language learning, new technology for learners, development of classroom resources, the establishment of a Qawmi Madrasa teaching college, implementation of authentic teaching materials within the classroom, and extension of English language education up to graduate level at Qawmi Madrasas. As they have not focused on specific skill development of the English language, the current study will try to fill that gap.

According to Richards and Rodgers (2001), second language (SL) or foreign language (FL) is best learned and taught through the target language itself. For them, the avoidance of mother tongue (MT) would maximize the effectiveness of learning the target language (TL), because maximum exposure to TL and least exposure to MT are of crucial importance, and the use of MT may obstruct the TL learning process (Cook, 2001; \& Krashen, 1981). Ruman and Bhuiyan (2015) found that the Qawmi madrasa textbooks are designed on Grammar-Translation (GT) method and usually the teachers do not teach the textbooks in English, the target language; rather they prefer to use their mother tongue Bangla in the English classroom. Furthermore, they never encourage their students to speak English in the classroom or outside. Consequently, these students lack motivation in learning English and cannot achieve communicative competence in English. To cite Alam (2005) in this regard, if we want to keep up with English studies of the rest of the world, we need to keep thinking of redesigning our curriculum (syllabus) and rethinking what we teach (materials) and how we teach (methodology) again and again.

Hoque (2008) has conducted a study on the state of English language teaching and learning at the Alim level of madrasa education. It has tried to unveil the problems encountered by the Aliya madrasas of Bangladesh in the process of EFL teachinglearning activities, evaluate the level of performance of students in the four basic skills of English language: listening, speaking, reading, and writing, and suggest certain remedial measures to overcome the underlying challenges. It is found that after many years of learning English, most of the learners cannot speak English with the necessary fluency, correctness of grammar, and pronunciation. It also reveals that the major problems in English language teaching and learning at this level lie with the textbook materials, syllabus, uninteresting lessons, method of teaching, poor quality of teachers, lack of classroom facilities, teaching aids, and equipment, etc. The majority of the students and the teachers think that the English syllabus is examination-oriented; rather than achieving communicative competence which was a major course objective. The fact is that only reading comprehension and writing skills are tested in the examination. But the two important skills-listening and speaking-are neglected or avoided. Consequently, the students are very weak in English listening and speaking. The study also manifests that most English teachers cannot speak English frequently in the classroom. This classroom practice or situation directly contradicts their prescribed communicative approach of teaching and learning the English language. Since Hoque's research problem, context and methods are similar to the current research to a great extent, this literature review correlates and justifies the present study.

Furthermore, Azad (2017) explores the challenges faced by the Alim level (grade XI \& XII) students of Bangladeshi Aliya Madrasa in learning English and evaluates their communicative competence in the English language. The study reveals that the main obstacles in learning English are the textbook materials, the teaching method, the teacher's lack of subject knowledge, the omission of two important skills (listening and speaking), the lack of appropriate equipment, large class size, and so on. Since the current study similarly intends to investigate the challenges in skill-focused language teaching in Qawmi madrasas where the main objective of the English syllabus is to make the students communicatively competent in English, Azad's study (2017) provides my research a relevant context.

There might be other issues than the ones found in these studies conducted with similar teaching contexts. For instance, none of these presents the in-depth analysis of aims and procedures of English teaching and learning with a specific focus on individual language skills, particularly in Qawmi madrasa education. Without exploring these areas, it is impossible to get a complete understanding of the challenges faced by English language teachers and students. To conclude, all the findings and comments of the literature review are a vibrant source of supportive information to the current study. Indeed, these studies help to signify and justify the present research as well as fix the research problem.

\section{Research Methodology}

Integrating both quantitative and qualitative methods, in this study the researcher used a mixed-methods approach to gain a comprehensive understanding of the research problem. The quantitative method includes questionnaire surveys because questionnaires allow flexibility in collecting controlled responses from a large number of participants in an economical way and can be distributed and collected face-to-face (McDonough, J. \& McDonough, S. 1997). On the other hand, the qualitative method includes focused semi-structured open-ended interviews and classroom observation. As Nunan (1992) indicates, interviews 
complement the data obtained from the questionnaires and add to the validity of the questionnaire responses (Xiao \& Petraki, 2007). Furthermore, the classroom observation tool can describe "what goes on in L2 classrooms between teachers and learners ... and the nature of the linguistic interactions that take place between them" (Spada, 2019). Thus, the mixed-methods approach will ensure multi-level analysis for the research. Besides, the researcher also had a glance at the Qawmi madrasa curriculum, English syllabus, and textbooks.

\section{Data Collection}

In this research 2 questionnaire surveys, 1 for the teachers and 1 for the students, were used to gather information about the basic English language skills teaching and learning situations. The questionnaire items were based on 5 point Likert scale (1=Strongly Disagree to $5=$ Strongly Agree) for frequency analysis in SPSS 21 . The survey participants were 11 teachers (exceptionally, there were 2 English teachers in one madrasa) and 152 students of grade $\mathrm{V}$ from 10 Qawmi madrasas (4 in urban, 3 sub-urban, and 3 rural areas) in Bangladesh. Here, it is noteworthy that the madrasas, the teachers, and the students are identified using numbers like 1, 2, 3, etc. Questionnaires were carried out face to face and almost in all cases items were translated in Bangla so that participants could ask for clarifications and respond with proper understanding. Then, questions for interviews were developed for further in-depth analysis based on the factual information derived from the questionnaire surveys. The individual interviews were conducted with 11 teachers and 20 meritorious students from 10 madrasas. It is to mention that the nonprobability purposive sampling method was applied in the case of the student interviewees because the meritorious students have detailed knowledge about the specific phenomenon of the study, i.e. the learning situation of 4 basic English language skills. The interview responses were recorded, transcribed, and coded categorically to emerge thematic content for qualitative analysis so that it would reveal specific personal experiences of the participants in relation to the research questions. Moreover, 5 classroom observations from each madrasa were noted because observation helps to gain understandings of the context with specific incidents and behaviors (Merriam, 1998 cited in Nguyen, 2015).

\section{Results and Discussion}

\subsection{Quantitative Data Analysis}

\subsubsection{Student's Questionnaire}

Table 1: Listening Skill

\begin{tabular}{|c|c|c|c|c|c|c|c|c|}
\hline & Statements & Item & $\begin{array}{l}1 \\
\text { SD }\end{array}$ & $\begin{array}{l}2 \\
\mathbf{D}\end{array}$ & $\begin{array}{l}\mathbf{3} \\
\mathbf{N}\end{array}$ & $\begin{array}{l}4 \\
\mathbf{A}\end{array}$ & $\begin{array}{l}5 \\
\text { SA }\end{array}$ & Total \\
\hline 1 & $\begin{array}{l}\text { We practice listening to English audio } \\
\text { tapes and answering relevant questions } \\
\text { in the classroom. }\end{array}$ & $\begin{array}{l}\mathrm{N} \\
\%\end{array}$ & $\begin{array}{l}126 \\
82.9\end{array}$ & $\begin{array}{l}1 \\
.7\end{array}$ & & $\begin{array}{l}23 \\
15.1\end{array}$ & $\begin{array}{l}2 \\
1.3\end{array}$ & $\begin{array}{l}(152) \\
100.0\end{array}$ \\
\hline 2 & $\begin{array}{l}\text { The English syllabus meets my needs } \\
\text { regarding listening skills. }\end{array}$ & $\begin{array}{l}\mathrm{N} \\
\% \\
\end{array}$ & $\begin{array}{l}140 \\
92.1 \\
\end{array}$ & $\begin{array}{l}2 \\
1.3 \\
\end{array}$ & $\begin{array}{l}2 \\
1.3 \\
\end{array}$ & $\begin{array}{l}3 \\
2.0 \\
\end{array}$ & $\begin{array}{l}5 \\
3.3 \\
\end{array}$ & $\begin{array}{l}(152) \\
100.0\end{array}$ \\
\hline 3 & $\begin{array}{l}\text { The English syllabus/textbooks do not } \\
\text { include any listening tasks. }\end{array}$ & $\begin{array}{l}\mathrm{N} \\
\% \\
\end{array}$ & $\begin{array}{l}3 \\
2.0 \\
\end{array}$ & $\begin{array}{l}1 \\
.7 \\
\end{array}$ & $\begin{array}{l}1 \\
.7 \\
\end{array}$ & $\begin{array}{l}2 \\
1.3 \\
\end{array}$ & $\begin{array}{l}145 \\
95.4 \\
\end{array}$ & $\begin{array}{l}(152) \\
100.0 \\
\end{array}$ \\
\hline 4 & $\begin{array}{l}\text { Sometimes I practice listening skills } \\
\text { outside the classroom by hearing the } \\
\text { English news and/or commentary on } \\
\text { international sports. }\end{array}$ & $\begin{array}{l}\mathrm{N} \\
\%\end{array}$ & $\begin{array}{l}22 \\
14.5\end{array}$ & $\begin{array}{l}17 \\
11.2\end{array}$ & $\begin{array}{l}18 \\
11.8\end{array}$ & $\begin{array}{l}55 \\
36.2\end{array}$ & $\begin{array}{l}40 \\
26.3\end{array}$ & $\begin{array}{l}(152) \\
100.0\end{array}$ \\
\hline
\end{tabular}

The table shows that most of the students do not practice their listening skills in the classroom at all. Except for a negligible number, almost all of them think that the English syllabus does not meet their needs regarding listening skills because the English textbooks do not include any listening activities. However, most of the students sometimes listen to English news or sports commentary, which indicates that they are motivated to acquire English listening skills.

Table 2: Speaking Skill

\begin{tabular}{|c|c|c|c|c|c|c|c|c|}
\hline & Statements & Item & $\begin{array}{l}1 \\
\text { SD }\end{array}$ & $\begin{array}{l}2 \\
D\end{array}$ & $\begin{array}{l}\mathbf{3} \\
\mathbf{N}\end{array}$ & $\begin{array}{l}4 \\
\mathrm{~A}\end{array}$ & $\begin{array}{l}5 \\
\text { SA }\end{array}$ & Total \\
\hline 1 & I speak only English in English classes. & $\begin{array}{l}\mathrm{N} \\
\% \\
\end{array}$ & $\begin{array}{l}126 \\
82.9 \\
\end{array}$ & $\begin{array}{l}15 \\
9.9 \\
\end{array}$ & $\begin{array}{l}3 \\
2.0 \\
\end{array}$ & $\begin{array}{l}2 \\
1.3 \\
\end{array}$ & $\begin{array}{l}6 \\
3.9 \\
\end{array}$ & $\begin{array}{l}(152) \\
100.0\end{array}$ \\
\hline 2 & I speak Bangla in English classes. & $\begin{array}{l}N \\
\%\end{array}$ & $\begin{array}{l}5 \\
3.3\end{array}$ & $\begin{array}{l}3 \\
2.0\end{array}$ & $\begin{array}{l}15 \\
9.9\end{array}$ & $\begin{array}{l}48 \\
31.6\end{array}$ & $\begin{array}{l}81 \\
53.3\end{array}$ & $\begin{array}{l}(152) \\
100.0\end{array}$ \\
\hline
\end{tabular}




\begin{tabular}{|c|c|c|c|c|c|c|c|c|}
\hline 3 & $\begin{array}{l}\text { The teacher arranges games, pair work, } \\
\text { group work, etc. for us to practice in the } \\
\text { English classroom. }\end{array}$ & $\begin{array}{l}\mathrm{N} \\
\%\end{array}$ & $\begin{array}{l}56 \\
36.8\end{array}$ & $\begin{array}{l}28 \\
18.4\end{array}$ & $\begin{array}{l}23 \\
15.1\end{array}$ & $\begin{array}{l}34 \\
22.4\end{array}$ & $\begin{array}{l}11 \\
7.2\end{array}$ & $\begin{array}{l}(152) \\
100.0\end{array}$ \\
\hline 4 & $\begin{array}{l}\text { The classroom environment is favorable to } \\
\text { practice speaking fluently in English. }\end{array}$ & $\begin{array}{l}\mathrm{N} \\
\% \\
\end{array}$ & $\begin{array}{l}20 \\
13.2\end{array}$ & $\begin{array}{l}27 \\
17.8\end{array}$ & $\begin{array}{l}20 \\
13.2\end{array}$ & $\begin{array}{l}50 \\
32.9\end{array}$ & $\begin{array}{l}35 \\
23.0\end{array}$ & $\begin{array}{l}(152) \\
100.0\end{array}$ \\
\hline 5 & $\begin{array}{l}\text { In English class, I get opportunities to } \\
\text { speak English in a group with my friends in } \\
\text { the classroom. }\end{array}$ & $\begin{array}{l}\mathrm{N} \\
\%\end{array}$ & $\begin{array}{l}45 \\
29.6\end{array}$ & $\begin{array}{l}26 \\
17.1\end{array}$ & $\begin{array}{l}6 \\
3.9\end{array}$ & $\begin{array}{l}52 \\
34.2\end{array}$ & $\begin{array}{l}23 \\
15.1\end{array}$ & $\begin{array}{l}(152) \\
100.0\end{array}$ \\
\hline 6 & $\begin{array}{l}\text { I am afraid of making mistakes while } \\
\text { speaking in English. }\end{array}$ & $\begin{array}{l}\mathrm{N} \\
\% \\
\end{array}$ & $\begin{array}{l}16 \\
10.5 \\
\end{array}$ & $\begin{array}{l}9 \\
5.9 \\
\end{array}$ & $\begin{array}{l}26 \\
17.1 \\
\end{array}$ & $\begin{array}{l}41 \\
27.0 \\
\end{array}$ & $\begin{array}{l}60 \\
39.5 \\
\end{array}$ & $\begin{array}{l}(152) \\
100.0 \\
\end{array}$ \\
\hline 7 & $\begin{array}{l}\text { The English syllabus meets my needs } \\
\text { regarding speaking skills. }\end{array}$ & $\begin{array}{l}\mathrm{N} \\
\%\end{array}$ & $\begin{array}{l}4 \\
2.6\end{array}$ & $\begin{array}{l}19 \\
12.5\end{array}$ & $\begin{array}{l}11 \\
7.2\end{array}$ & $\begin{array}{l}99 \\
65.1\end{array}$ & $\begin{array}{l}19 \\
12.5\end{array}$ & $\begin{array}{l}(152) \\
100.0\end{array}$ \\
\hline
\end{tabular}

According to Cook (2001) and Krashen (1981), maximum exposure to the target language (TL) and least exposure to the mother tongue (MT) are of crucial importance, and the use of MT may obstruct the TL learning process. But the table reveals that about $5 \%$ of students only speak in the target language (English) and approximately $85 \%$ speak in the mother language (Bangla) in an English classroom which can affect their EFL learning adversely. Regarding the language instructor's moderating speaking activities in the English classroom, though a minimum number of students responded positively, a maximum number of them replied negatively. However, most of them consider the classroom environment to be favorable to practice speaking in English. Therefore, half of them get opportunities provided by the teacher to interact with their friends in English, whereas approximately half do not. Data from the respondents reveal that majority of them also hesitate to speak in English fearing mistakes. So, from the students' perspectives, it can be deducted that the speaking skill is neither taught nor practiced in the English language classroom satisfactorily.

Table 3: Reading Skill

\begin{tabular}{|c|c|c|c|c|c|c|c|c|}
\hline & Statements & Item & $\begin{array}{l}1 \\
\text { SD }\end{array}$ & $\begin{array}{l}2 \\
\mathbf{D}\end{array}$ & $\begin{array}{l}\mathbf{3} \\
\mathbf{N}\end{array}$ & $\begin{array}{l}4 \\
\text { A }\end{array}$ & $\begin{array}{l}5 \\
\text { SA }\end{array}$ & Total \\
\hline 1 & $\begin{array}{l}\text { We get opportunities to practice reading } \\
\text { from the English textbooks in the } \\
\text { classroom }\end{array}$ & $\begin{array}{l}\mathrm{N} \\
\%\end{array}$ & & & & $\begin{array}{l}22 \\
14.5\end{array}$ & $\begin{array}{l}130 \\
85.5\end{array}$ & $\begin{array}{l}(152) \\
100.0\end{array}$ \\
\hline 2 & $\begin{array}{l}\text { I am afraid of making incorrect } \\
\text { pronunciation while reading aloud in class. }\end{array}$ & $\begin{array}{l}\mathrm{N} \\
\% \\
\end{array}$ & $\begin{array}{l}14 \\
9.2\end{array}$ & $\begin{array}{l}21 \\
13.8 \\
\end{array}$ & $\begin{array}{l}6 \\
3.9 \\
\end{array}$ & $\begin{array}{l}67 \\
44.1 \\
\end{array}$ & $\begin{array}{l}44 \\
28.9 \\
\end{array}$ & $\begin{array}{l}(152) \\
100.0\end{array}$ \\
\hline 3 & $\begin{array}{l}\text { While we read out from the textbooks in } \\
\text { the classroom, our teacher corrects our } \\
\text { mistakes. }\end{array}$ & $\begin{array}{l}\mathrm{N} \\
\%\end{array}$ & $\begin{array}{l}1 \\
.7\end{array}$ & & $\begin{array}{l}1 \\
.7\end{array}$ & $\begin{array}{l}6 \\
3.9\end{array}$ & $\begin{array}{l}144 \\
94.7\end{array}$ & $\begin{array}{l}(152) \\
100.0\end{array}$ \\
\hline 4 & $\begin{array}{l}\text { To understand each and every word I read, } \\
\text { I always need a dictionary as an aid. }\end{array}$ & $\begin{array}{l}\mathrm{N} \\
\% \\
\end{array}$ & $\begin{array}{l}2 \\
1.3 \\
\end{array}$ & $\begin{array}{l}2 \\
1.3 \\
\end{array}$ & $\begin{array}{l}6 \\
3.9 \\
\end{array}$ & $\begin{array}{l}26 \\
17.1 \\
\end{array}$ & $\begin{array}{l}116 \\
76.3 \\
\end{array}$ & $\begin{array}{l}(152) \\
100.0\end{array}$ \\
\hline 5 & $\begin{array}{l}\text { To me, English reading is a tedious task as } \\
\text { it needs the frequent use of a bilingual } \\
\text { dictionary. }\end{array}$ & $\begin{array}{l}\mathrm{N} \\
\%\end{array}$ & $\begin{array}{l}13 \\
8.6\end{array}$ & $\begin{array}{l}35 \\
23.0\end{array}$ & $\begin{array}{l}15 \\
9.9\end{array}$ & $\begin{array}{l}49 \\
32.2\end{array}$ & $\begin{array}{l}40 \\
26.3\end{array}$ & $\begin{array}{l}(152) \\
100.0\end{array}$ \\
\hline 6 & $\begin{array}{l}\text { I find comprehension questions helpful in } \\
\text { arriving at the meaning of a text. }\end{array}$ & $\begin{array}{l}\mathrm{N} \\
\% \\
\end{array}$ & $\begin{array}{l}2 \\
1.3 \\
\end{array}$ & $\begin{array}{l}10 \\
6.6 \\
\end{array}$ & $\begin{array}{l}6 \\
3.9 \\
\end{array}$ & $\begin{array}{l}64 \\
42.1 \\
\end{array}$ & $\begin{array}{l}70 \\
46.1 \\
\end{array}$ & $\begin{array}{l}(152) \\
100.0\end{array}$ \\
\hline 7 & $\begin{array}{l}\text { We practice answering questions and filling } \\
\text { up gaps with required information from the } \\
\text { reading paragraph. }\end{array}$ & $\begin{array}{l}\mathrm{N} \\
\%\end{array}$ & $\begin{array}{l}4 \\
2.6\end{array}$ & $\begin{array}{l}8 \\
5.3\end{array}$ & $\begin{array}{l}5 \\
3.3\end{array}$ & $\begin{array}{l}45 \\
29.6\end{array}$ & $\begin{array}{l}90 \\
59.2\end{array}$ & $\begin{array}{l}(152) \\
100.0\end{array}$ \\
\hline 8 & $\begin{array}{l}\text { I am satisfied with the quality of the reading } \\
\text { skill taught in the English subject. }\end{array}$ & $\begin{array}{l}\mathrm{N} \\
\%\end{array}$ & $\begin{array}{l}3 \\
2.0\end{array}$ & $\begin{array}{l}4 \\
2.6\end{array}$ & $\begin{array}{l}5 \\
3.3\end{array}$ & $\begin{array}{l}41 \\
27.0\end{array}$ & $\begin{array}{l}99 \\
65.1\end{array}$ & $\begin{array}{l}(152) \\
100.0\end{array}$ \\
\hline 9 & $\begin{array}{l}\text { Besides the textbooks, I read English } \\
\text { outside the classroom. }\end{array}$ & $\begin{array}{l}\mathrm{N} \\
\% \\
\end{array}$ & $\begin{array}{l}52 \\
34.2 \\
\end{array}$ & $\begin{array}{l}27 \\
17.8 \\
\end{array}$ & $\begin{array}{l}17 \\
11.2 \\
\end{array}$ & $\begin{array}{l}42 \\
27.6 \\
\end{array}$ & $\begin{array}{l}14 \\
9.2 \\
\end{array}$ & $\begin{array}{l}(152) \\
100.0\end{array}$ \\
\hline
\end{tabular}

Data in the table clearly show that all the students can practice reading from the English textbooks in the classroom. However, about three-fourths of them fear pronunciation mistakes, though almost all the respondents agree that their teacher 
corrects the mistakes. Again, almost all of them need a bilingual dictionary for word meaning, even though it appears to be a tedious task for most of this group. The results demonstrate that the student's skill in English reading comprehension is very satisfactory, although only one-third of them read English beyond the textbooks. Here, it is evident that reading English out of the classroom is, to some extent, a negligible area among the students. In fact, resorting to different reading materials in the target language is helpful for the learners to develop their reading habits which will surely improve their comprehension ability. It can also widen their vocabulary and make them good readers (Junias, 2009). Furthermore, Krarzia (2013) states in this regard, "Reading English-written documents is very important for students because it helps them acquire the needed vocabulary and the necessary style to improve their writings" (p. 86).

Table 4: Writing Skill

\begin{tabular}{|c|c|c|c|c|c|c|c|c|}
\hline & Statements & Item & $\begin{array}{l}1 \\
\text { SD }\end{array}$ & $\begin{array}{l}2 \\
\text { D }\end{array}$ & $\begin{array}{l}\mathbf{3} \\
\mathbf{N} \\
\end{array}$ & $\begin{array}{l}4 \\
\mathbf{A}\end{array}$ & $\begin{array}{l}5 \\
\text { SA }\end{array}$ & Total \\
\hline 1 & $\begin{array}{l}\text { We practice writing according to the } \\
\text { syllabus in the English classroom }\end{array}$ & $\begin{array}{l}\mathrm{N} \\
\%\end{array}$ & $\begin{array}{l}1 \\
.7\end{array}$ & $\begin{array}{l}14 \\
9.2\end{array}$ & $\begin{array}{l}4 \\
2.6 \\
\end{array}$ & $\begin{array}{l}42 \\
27.6\end{array}$ & $\begin{array}{l}91 \\
59.9\end{array}$ & $\begin{array}{l}(152) \\
100.0\end{array}$ \\
\hline 2 & $\begin{array}{l}\text { The teacher discusses the topic of } \\
\text { writing/composition before he asks us } \\
\text { to write on that in the classroom/at } \\
\text { home. }\end{array}$ & $\begin{array}{l}\mathrm{N} \\
\%\end{array}$ & $\begin{array}{l}2 \\
1.3\end{array}$ & $\begin{array}{l}2 \\
1.3\end{array}$ & $\begin{array}{l}7 \\
4.6\end{array}$ & $\begin{array}{l}43 \\
28.3\end{array}$ & $\begin{array}{l}98 \\
64.5\end{array}$ & $\begin{array}{l}(152) \\
100.0\end{array}$ \\
\hline 3 & $\begin{array}{l}\text { The teacher inspires us to brainstorm for } \\
\text { finding out words related to the topic }\end{array}$ & $\begin{array}{l}\mathrm{N} \\
\% \\
\end{array}$ & $\begin{array}{l}4 \\
2.6 \\
\end{array}$ & $\begin{array}{l}11 \\
7.2 \\
\end{array}$ & $\begin{array}{l}10 \\
6.6 \\
\end{array}$ & $\begin{array}{l}60 \\
39.5 \\
\end{array}$ & $\begin{array}{l}67 \\
44.1 \\
\end{array}$ & $\begin{array}{l}(152) \\
100.0 \\
\end{array}$ \\
\hline 4 & $\begin{array}{l}\text { We brainstorm ideas before writing a } \\
\text { composition. }\end{array}$ & $\begin{array}{l}\mathrm{N} \\
\%\end{array}$ & $\begin{array}{l}6 \\
3.9 \\
\end{array}$ & $\begin{array}{l}9 \\
5.9\end{array}$ & $\begin{array}{l}21 \\
13.8\end{array}$ & $\begin{array}{l}46 \\
30.3\end{array}$ & $\begin{array}{l}70 \\
46.1 \\
\end{array}$ & $\begin{array}{l}(152) \\
100.0\end{array}$ \\
\hline 5 & $\begin{array}{l}\text { In English class, we get opportunities to } \\
\text { write English (e.g. paragraph, essay, } \\
\text { letter, etc) independently on our own. }\end{array}$ & $\begin{array}{l}\mathrm{N} \\
\%\end{array}$ & $\begin{array}{l}5 \\
3.3\end{array}$ & $\begin{array}{l}12 \\
7.9\end{array}$ & $\begin{array}{l}7 \\
4.6\end{array}$ & $\begin{array}{l}59 \\
38.8\end{array}$ & $\begin{array}{l}69 \\
45.4\end{array}$ & $\begin{array}{l}(152) \\
100.0\end{array}$ \\
\hline 6 & $\begin{array}{l}\text { I have to memorize letters, paragraphs, } \\
\text { and essays for writing tasks in the } \\
\text { classroom. }\end{array}$ & $\begin{array}{l}\mathrm{N} \\
\%\end{array}$ & $\begin{array}{l}1 \\
.7\end{array}$ & $\begin{array}{l}4 \\
2.6\end{array}$ & $\begin{array}{l}1 \\
.7\end{array}$ & $\begin{array}{l}32 \\
21.1\end{array}$ & $\begin{array}{l}114 \\
75.0\end{array}$ & $\begin{array}{l}(152) \\
100.0\end{array}$ \\
\hline 7 & $\begin{array}{l}\text { I am satisfied with the quality of the } \\
\text { writing skill taught in the English course. }\end{array}$ & $\begin{array}{l}\mathrm{N} \\
\% \\
\end{array}$ & $\begin{array}{l}1 \\
.7 \\
\end{array}$ & $\begin{array}{l}2 \\
1.3 \\
\end{array}$ & $\begin{array}{l}18 \\
11.8 \\
\end{array}$ & $\begin{array}{l}36 \\
23.7\end{array}$ & $\begin{array}{l}95 \\
62.5 \\
\end{array}$ & $\begin{array}{l}(152) \\
100.0 \\
\end{array}$ \\
\hline 8 & $\begin{array}{l}\text { I like my teacher to evaluate my writing } \\
\text { and correct all mistakes. }\end{array}$ & $\begin{array}{l}\mathrm{N} \\
\%\end{array}$ & $\begin{array}{l}2 \\
1.3\end{array}$ & & $\begin{array}{l}1 \\
.7\end{array}$ & $\begin{array}{l}9 \\
5.9\end{array}$ & $\begin{array}{l}140 \\
92.1\end{array}$ & $\begin{array}{l}(152) \\
100.0\end{array}$ \\
\hline 9 & $\begin{array}{l}\text { I am afraid of writing because the } \\
\text { teacher marks my writing. }\end{array}$ & $\begin{array}{l}\mathrm{N} \\
\%\end{array}$ & $\begin{array}{l}25 \\
16.4\end{array}$ & $\begin{array}{l}27 \\
17.8\end{array}$ & $\begin{array}{l}15 \\
9.9\end{array}$ & $\begin{array}{l}56 \\
36.8\end{array}$ & $\begin{array}{l}29 \\
19.1\end{array}$ & $\begin{array}{l}(152) \\
100.0\end{array}$ \\
\hline 10 & $\begin{array}{l}\text { The teacher encourages us to overcome } \\
\text { fear and anxiety in writing. }\end{array}$ & $\begin{array}{l}\mathrm{N} \\
\% \\
\end{array}$ & $\begin{array}{l}4 \\
2.6 \\
\end{array}$ & $\begin{array}{l}3 \\
2.0 \\
\end{array}$ & $\begin{array}{l}3 \\
2.0 \\
\end{array}$ & $\begin{array}{l}16 \\
10.5 \\
\end{array}$ & $\begin{array}{l}126 \\
82.9 \\
\end{array}$ & $\begin{array}{l}(152) \\
100.0 \\
\end{array}$ \\
\hline 11 & $\begin{array}{l}\text { The teacher's feedback helps me to } \\
\text { improve my writing. }\end{array}$ & $\begin{array}{l}\mathrm{N} \\
\% \\
\end{array}$ & & & $\begin{array}{l}4 \\
2.6 \\
\end{array}$ & $\begin{array}{l}17 \\
11.2 \\
\end{array}$ & $\begin{array}{l}131 \\
86.2 \\
\end{array}$ & $\begin{array}{l}(152) \\
100.0 \\
\end{array}$ \\
\hline 12 & $\begin{array}{l}\text { Sometimes the teacher encourages us } \\
\text { to write in pairs/groups to correct each } \\
\text { other. }\end{array}$ & $\begin{array}{l}\mathrm{N} \\
\%\end{array}$ & $\begin{array}{l}18 \\
11.8\end{array}$ & $\begin{array}{l}24 \\
15.8\end{array}$ & $\begin{array}{l}18 \\
11.8\end{array}$ & $\begin{array}{l}59 \\
38.8\end{array}$ & $\begin{array}{l}33 \\
21.7\end{array}$ & $\begin{array}{l}(152) \\
100.0\end{array}$ \\
\hline
\end{tabular}

According to Krarzia (2013), "The writing skill is very important for the students... They will obviously be required to answer comprehension questions or write topics specific to their field, which both require a good knowledge of grammatical aspects and writing rules" (p. 85). As the results show, all but a few students practice writing according to the syllabus in the English classroom and the teacher supports them as required. From their responses, it seems that almost all of them can practice free-hand writing in the classroom, though few students do not agree with that. Meanwhile, data reveal that almost all of the students depend on memorization for writing tasks. Still, they seem to be happy with the teaching standard of English writing skills with the teacher's feedback. It is also found that the majority of them fear the teacher's marking in their writing, though approximately all agree that the teacher tries to remove this fear and anxiety. That is why most of them like to correct one another's mistakes in writing. The findings from the students' survey indicate that their level of acquiring the writing skill in English is satisfactory. 


\subsubsection{Teacher's Questionnaire}

Table 5: Listening Skill

\begin{tabular}{|c|c|c|c|c|c|c|c|c|}
\hline & Statements & Item & $\begin{array}{l} \\
\text { SD }\end{array}$ & $\begin{array}{l}2 \\
\mathrm{D}\end{array}$ & $\begin{array}{l}\mathbf{3} \\
\mathbf{N}\end{array}$ & $\begin{array}{l}4 \\
\mathbf{A}\end{array}$ & $\begin{array}{l}5 \\
\text { SA }\end{array}$ & Total \\
\hline 1 & $\begin{array}{l}\text { The syllabus/textbooks suggest some } \\
\text { practices on listening skills. }\end{array}$ & $\begin{array}{l}\mathrm{N} \\
\% \\
\end{array}$ & $\begin{array}{l}3 \\
27.3 \\
\end{array}$ & $\begin{array}{l}2 \\
18.2 \\
\end{array}$ & & $\begin{array}{l}3 \\
27.3 \\
\end{array}$ & $\begin{array}{l}3 \\
27.3 \\
\end{array}$ & $\begin{array}{l}(11) \\
100.0\end{array}$ \\
\hline 2 & $\begin{array}{l}\text { I play audio cassettes for the students to } \\
\text { practice and develop the listening skill in } \\
\text { English. }\end{array}$ & $\begin{array}{l}\mathrm{N} \\
\%\end{array}$ & $\begin{array}{l}3 \\
27.3\end{array}$ & $\begin{array}{l}3 \\
27.3\end{array}$ & $\begin{array}{l}1 \\
9.1\end{array}$ & $\begin{array}{l}3 \\
27.3\end{array}$ & $\begin{array}{l}1 \\
9.1\end{array}$ & $\begin{array}{l}111) \\
100.0\end{array}$ \\
\hline 3 & $\begin{array}{l}\text { I do not make students practice the } \\
\text { listening skill because it is not included in } \\
\text { the syllabus. }\end{array}$ & $\begin{array}{l}\mathrm{N} \\
\%\end{array}$ & $\begin{array}{l}2 \\
18.2\end{array}$ & $\begin{array}{l}2 \\
18.2\end{array}$ & & $\begin{array}{l}4 \\
36.4\end{array}$ & $\begin{array}{l}3 \\
27.3\end{array}$ & $\begin{array}{l}(11) \\
100.0\end{array}$ \\
\hline 4 & $\begin{array}{l}\text { I need a laboratory equipped with a sound } \\
\text { system or at least a cassette player to teach } \\
\text { the listening skill. }\end{array}$ & $\begin{array}{l}\mathrm{N} \\
\%\end{array}$ & $\begin{array}{l}1 \\
9.1\end{array}$ & $\begin{array}{l}1 \\
9.1\end{array}$ & $\begin{array}{l}2 \\
18.2\end{array}$ & $\begin{array}{l}2 \\
18.2\end{array}$ & $\begin{array}{l}5 \\
45.5\end{array}$ & $\begin{array}{l}(11) \\
100.0\end{array}$ \\
\hline
\end{tabular}

As the table shows, most of the teachers think that the English syllabus and textbooks suggest some practices on the listening skill, while actually no listening tasks or exercises were found at all in the textbooks. But most of them frankly express that they do not play English audio cassettes for the students to develop their listening skills because it is, in fact, not included in the syllabus. Through this response, they show their adherence to the limited teaching contents of the target language. On the other hand, the data indicate that to impart effective training to students in this first basic language skill, the great majority of the teachers stressed the need for providing a well-equipped language laboratory with relevant modern technology which is a big challenge for economically backward Qawmi madrasas in general.

Table 6: Speaking Skill

\begin{tabular}{|c|c|c|c|c|c|c|c|c|}
\hline & Statements & Item & $\begin{array}{l}1 \\
S D\end{array}$ & $\begin{array}{l}2 \\
D\end{array}$ & $\begin{array}{l}\mathbf{3} \\
\mathbf{N} \\
\end{array}$ & $\begin{array}{l}4 \\
\mathrm{~A}\end{array}$ & $\begin{array}{l}5 \\
\text { SA } \\
\end{array}$ & Total \\
\hline 1 & $\begin{array}{l}\text { The syllabus/textbooks include } \\
\text { adequate tasks (e.g. dialogue) on } \\
\text { speaking skills. }\end{array}$ & $\begin{array}{l}\mathrm{N} \\
\%\end{array}$ & $\begin{array}{l}3 \\
27.3\end{array}$ & $\begin{array}{l}2 \\
18.2\end{array}$ & & $\begin{array}{l}3 \\
27.3\end{array}$ & $\begin{array}{l}3 \\
27.3\end{array}$ & $\begin{array}{l}(11) \\
100.0\end{array}$ \\
\hline 2 & $\begin{array}{l}\text { In the classroom, students get } \\
\text { opportunities to speak English on their } \\
\text { own as individual/pair/group work. }\end{array}$ & $\begin{array}{l}\mathrm{N} \\
\%\end{array}$ & $\begin{array}{l}1 \\
9.1\end{array}$ & $\begin{array}{l}1 \\
9.1\end{array}$ & $\begin{array}{l}1 \\
9.1\end{array}$ & $\begin{array}{l}5 \\
45.5\end{array}$ & $\begin{array}{l}3 \\
27.3\end{array}$ & $\begin{array}{l}(11) \\
100.0\end{array}$ \\
\hline 3 & $\begin{array}{l}\text { In English class, students get } \\
\text { opportunities to practice English that is } \\
\text { necessary for different social situations } \\
\text { (e.g. at the bus stop, library, etc.) }\end{array}$ & $\begin{array}{l}\mathrm{N} \\
\%\end{array}$ & $\begin{array}{l}2 \\
18.2\end{array}$ & $\begin{array}{l}1 \\
9.1\end{array}$ & $\begin{array}{l}2 \\
18.2\end{array}$ & $\begin{array}{l}3 \\
27.3\end{array}$ & $\begin{array}{l}3 \\
27.3\end{array}$ & $\begin{array}{l}(11) \\
100.0\end{array}$ \\
\hline 4 & $\begin{array}{l}\text { Sometimes I arrange class tests, quizzes, } \\
\text { etc on speaking skills. }\end{array}$ & $\begin{array}{l}\mathrm{N} \\
\%\end{array}$ & $\begin{array}{l}1 \\
9.1 \\
\end{array}$ & $\begin{array}{l}1 \\
9.1\end{array}$ & & $\begin{array}{l}4 \\
36.4 \\
\end{array}$ & $\begin{array}{l}5 \\
45.5 \\
\end{array}$ & $\begin{array}{l}(11) \\
100.0\end{array}$ \\
\hline
\end{tabular}

According to the findings, 6 teachers believe that the English syllabus or textbooks include adequate tasks (e.g. dialogue) on the speaking skill and 5 teachers do not think so. In fact, analyzing the English textbooks the researcher found very few dialogues. The result indicates that more than $80 \%$ of teachers give their students opportunities to speak in English independently or interact with others in the classroom. According to most of the teachers, students also get opportunities to communicate in English in real-life situations. Indeed, these are necessary for achieving communicative competence in the target language, the main objective of the English course in Qawmi madrasa. Except for 2 teachers, all others reveal that they arrange class tests, quizzes, etc. on the speaking skill, though such activities were never available in classroom observations. 
Table 7: Reading Skill

\begin{tabular}{|c|c|c|c|c|c|c|c|c|}
\hline & Statements & Item & $\begin{array}{l}1 \\
S D\end{array}$ & $\begin{array}{l}2 \\
\mathbf{D}\end{array}$ & $\begin{array}{l}3 \\
\mathbf{N}\end{array}$ & $\begin{array}{l}4 \\
\mathbf{A}\end{array}$ & $\begin{array}{l}5 \\
\text { SA }\end{array}$ & Total \\
\hline 1 & $\begin{array}{l}\text { The syllabus/textbooks contain enough } \\
\text { lessons on reading skills. }\end{array}$ & $\begin{array}{l}\mathrm{N} \\
\%\end{array}$ & $\begin{array}{ll}2 \\
18.2 \\
\end{array}$ & $\begin{array}{ll}3 \\
27.3 \\
\end{array}$ & $\begin{array}{ll}1 \\
9.1 \\
\end{array}$ & $\begin{array}{ll}2 \\
18.2 \\
\end{array}$ & $\begin{array}{ll}3 \\
27.3 \\
\end{array}$ & $\begin{array}{ll}(11) \\
100.0\end{array}$ \\
\hline 2 & $\begin{array}{l}\text { I give more importance to my students' } \\
\text { developing the reading and writing skills in } \\
\text { English. }\end{array}$ & $\begin{array}{l}\mathrm{N} \\
\%\end{array}$ & & & & $\begin{array}{l}3 \\
27.3\end{array}$ & $\begin{array}{l}8 \\
72.7\end{array}$ & $\begin{array}{l}(11) \\
100.0\end{array}$ \\
\hline 3 & $\begin{array}{l}\text { I encourage my students to preview the } \\
\text { title/heading and photo (caption) to get a } \\
\text { sense of the content of a reading } \\
\text { passage/comprehension. }\end{array}$ & $\begin{array}{l}\mathrm{N} \\
\%\end{array}$ & & $\begin{array}{l}3 \\
27.3\end{array}$ & & $\begin{array}{l}4 \\
36.4\end{array}$ & $\begin{array}{l}4 \\
36.4\end{array}$ & $\begin{array}{l}(11) \\
100.0\end{array}$ \\
\hline 4 & $\begin{array}{l}\text { While reading a text if the students come } \\
\text { across any unknown vocabulary, I } \\
\text { encourage them to guess the meaning from } \\
\text { the context/word association. }\end{array}$ & $\begin{array}{l}\mathrm{N} \\
\%\end{array}$ & & & $\begin{array}{l}1 \\
9.1\end{array}$ & $\begin{array}{l}3 \\
27.3\end{array}$ & $\begin{array}{l}7 \\
63.6\end{array}$ & $\begin{array}{l}(11) \\
100.0\end{array}$ \\
\hline 5 & $\begin{array}{l}\text { In reading class, I ask the students to } \\
\text { mark/underline the unknown vocabulary } \\
\text { and explain the meaning in Bangla. }\end{array}$ & $\begin{array}{l}\mathrm{N} \\
\%\end{array}$ & & & & $\begin{array}{l}3 \\
27.3\end{array}$ & $\begin{array}{l}8 \\
72.7\end{array}$ & $\begin{array}{l}(11) \\
100.0\end{array}$ \\
\hline 6 & $\begin{array}{l}\text { In the classroom, I usually read the English } \\
\text { text aloud in the classroom and } \\
\text { translate/explain the meaning in the Bangla } \\
\text { language. }\end{array}$ & $\begin{array}{l}\mathrm{N} \\
\%\end{array}$ & & & & $\begin{array}{l}2 \\
18.2\end{array}$ & $\begin{array}{ll}9 \\
81.8\end{array}$ & $\begin{array}{l}(11) \\
100.0\end{array}$ \\
\hline 7 & $\begin{array}{l}\text { I correct the mistakes/pronunciation of my } \\
\text { students while they read out from the } \\
\text { textbooks in the classroom. }\end{array}$ & $\begin{array}{l}\mathrm{N} \\
\%\end{array}$ & & $\begin{array}{l}1 \\
9.1\end{array}$ & & & $\begin{array}{l}10 \\
90.9\end{array}$ & $\begin{array}{l}(11) \\
100.0\end{array}$ \\
\hline
\end{tabular}

The table shows the teachers are equally divided in their opinion whether the syllabus or textbooks contain enough lessons on reading skills or not. But it is noteworthy that $100 \%$ of teachers give importance to develop their students' reading and writing skills in English. Thereby, they devalue or put less emphasis on developing the learners' listening and speaking skills. Again, it is evident from the data that the Grammar-Translation method is used to teach English in Qawmi madrasa. For instance, all of them respond that they translate the reading passage from the TL (English) to the MT (Bangla) for a better understanding of the EFL learners. This fact was also manifested in classroom observations. However, the responses demonstrate that majority of the teachers teach different skills and strategies of reading comprehension. Besides, all of them tend to provide corrective feedback while their students commit any errors in reading activities.

Table 8: Writing Skill

\begin{tabular}{|l|l|l|l|l|l|l|l|l|}
\hline & Statements & Item & $\begin{array}{l}\mathbf{1} \\
\text { SD }\end{array}$ & $\begin{array}{l}\mathbf{2} \\
\mathbf{D}\end{array}$ & $\begin{array}{l}\mathbf{3} \\
\mathbf{N}\end{array}$ & $\begin{array}{l}\mathbf{4} \\
\mathbf{A}\end{array}$ & $\begin{array}{l}\mathbf{5} \\
\text { SA }\end{array}$ & Total \\
\hline $\mathbf{1}$ & $\begin{array}{l}\text { The syllabus/textbooks provide } \\
\text { sufficient content on writing skills. }\end{array}$ & $\mathbf{N}$ & 1 & 4 & 1 & 1 & 4 & $(11)$ \\
& $\%$ & 9.1 & 36.4 & 9.1 & 9.1 & 36.4 & 100.0 \\
\hline $\mathbf{2}$ & $\begin{array}{l}\text { I spend a few minutes on prewriting } \\
\text { activities. }\end{array}$ & $\mathbf{N}$ & & 1 & 1 & 3 & 6 & $(11)$ \\
& $\%$ & & 9.1 & 9.1 & 27.3 & 54.5 & 100.0 \\
\hline $\mathbf{3}$ & $\begin{array}{l}\text { I teach them how to organize ideas in an } \\
\text { outline form as a plan for writing. }\end{array}$ & $\mathbf{N}$ & & & & 5 & 6 & $(11)$ \\
& $\%$ & & & & 45.5 & 54.5 & 100.0 \\
\hline $\mathbf{4}$ & $\begin{array}{l}\text { I make them write on topics that are } \\
\text { important for the final examination. }\end{array}$ & $\mathrm{N}$ & & & & 2 & 9 & $(11)$ \\
& $\%$ & & & & 18.2 & 81.8 & 100.0 \\
\hline $\mathbf{5}$ & $\begin{array}{l}\text { In my class, students get opportunities } \\
\text { to write English on their own. }\end{array}$ & $\mathrm{N}$ & & 1 & 1 & 4 & 5 & $(11)$ \\
& $\%$ & & 9.1 & 9.1 & 36.4 & 45.5 & 100.0 \\
\hline $\mathbf{6}$ & $\begin{array}{l}\text { Sometimes I discuss orally a topic } \\
\text { before telling the students to write on it. }\end{array}$ & $\mathrm{N}$ & & 1 & & 3 & 7 & $(11)$ \\
& $\%$ & & 9.1 & & 27.3 & 63.6 & 100.0 \\
\hline $\mathbf{7}$ & $\begin{array}{l}\text { I motivate the students to creatively } \\
\text { practice free-hand writing in English. }\end{array}$ & $\mathrm{N}$ & & 1 & 1 & 3 & 6 & $(11)$ \\
& $\%$ & & 9.1 & 9.1 & 27.3 & 54.5 & 100.0 \\
\hline
\end{tabular}




\begin{tabular}{|c|c|c|c|c|c|c|c|c|}
\hline 8 & $\begin{array}{l}\text { I encourage the students to memorize } \\
\text { letters, applications, and essays. }\end{array}$ & $\begin{array}{l}\mathrm{N} \\
\% \\
\end{array}$ & $\begin{array}{l}3 \\
27.3\end{array}$ & $\begin{array}{l}1 \\
9.1 \\
\end{array}$ & & $\begin{array}{l}3 \\
27.3\end{array}$ & $\begin{array}{l}4 \\
36.4\end{array}$ & $\begin{array}{l}(11) \\
100.0\end{array}$ \\
\hline 9 & $\begin{array}{l}\text { I peer-review the students' writing and } \\
\text { immediately correct the mistakes } \\
\text { individually. }\end{array}$ & $\begin{array}{l}\mathrm{N} \\
\%\end{array}$ & & & $\begin{array}{l}1 \\
9.1\end{array}$ & $\begin{array}{l}4 \\
36.4\end{array}$ & $\begin{array}{l}6 \\
54.5\end{array}$ & $\begin{array}{l}(11) \\
100.0\end{array}$ \\
\hline 10 & $\begin{array}{l}\text { In writing tasks, I focus mainly on } \\
\text { grammar, spelling, vocabulary, and } \\
\text { punctuation. }\end{array}$ & $\begin{array}{l}\mathrm{N} \\
\%\end{array}$ & & $\begin{array}{l}1 \\
9.1\end{array}$ & & $\begin{array}{l}6 \\
54.5\end{array}$ & $\begin{array}{l}4 \\
36.4\end{array}$ & $\begin{array}{l}(11) \\
100.0\end{array}$ \\
\hline
\end{tabular}

Data in the table reveal that among the total number of participants, nearly half of them consider the English textbook contents as sufficient for teaching the writing skill and the same number of teachers think otherwise. Except 1 teacher, all others spend few minutes with students on the prewriting activities before doing the target writing task in the classroom. Moreover, all the teachers teach writing as an outline form. The result also shows that all the teachers focus on selective writing practices and it indicates that their teaching is basically exam-oriented; rather than being skill-focused. Meanwhile, all but 1 of them reveal that in their class they motivate the students to practice creative writing on different topics which are really important for effective language teaching. Additionally, the same number of teachers sometimes discuss a topic before assigning the writing task which is also helpful for the students to generate ideas freely on it. In contrast, it is found that most of the teachers not only support but also focus on the students' practice of memorizing the lessons instead of writing on their own. Indeed, this trend may subsequently affect the students' creative hand-writing ability. However, almost all the respondents demonstrate their corrective feedback to the mistakes that the students make in their writing tasks. Finally, it is apparent that except for one teacher all others stick to the traditional Grammar-Translation method by focusing mainly on grammar, spelling, vocabulary, and punctuation of writing.

\subsection{Qualitative Data Analysis}

\subsubsection{Teachers' and Students' Interviews}

Interviews were conducted with 11 teachers and 20 students to know how English listening, speaking, reading, and writing skills are taught and learned in Class $V$ and what challenges the teachers and the students encounter in the processes of teaching and learning. The analysis of the interviews was done using thematic content analysis where the researcher found the following scenario:

\section{Teaching and Learning English Listening Skill}

As the interview reveals, the majority of the teachers do not teach the listening skill of the English language because it is not included in the English syllabus and testing. For instance, Teacher 1 expressed, "The Madrasa Board hasn't included any listening skill in the English syllabus and testing. As the teachers have to follow their pattern, I don't teach this skill in class." His response demonstrates that the madrasa curriculum has some restrictions in teaching English language skills in the classroom. However, he thought that "if the Madrasa Board introduced the listening and the speaking skills, it would be very well. For instance, it would have been better if the students were asked questions based on original audios [authentic material] of the native speakers." Thus, he suggests the inclusion of this skill. Again, Teacher 7 does not teach listening because "it has not been arranged by the authority." He indicates that teaching the listening skill depends on the madrasa administration. Moreover, some cannot materialize it due to financial problems and lack of materials in the classroom. As Teacher 8 responded, "I don't teach listening in class due to the lack of necessary equipment." On the other hand, Teacher 9 cannot apply the listening skill in Class V "because of the shortage of time."

However, some teachers are interested to teach listening skills. For example, Teacher 3 is "planning to play the audio cassettes of TOEFL, SAT, BBC, etc. in free time, out of class hours, and make the students listen to them". Still, it seems to be of secondary importance to him because he is not thinking about practicing English listening in the classroom. Anyway, Teacher 10 sometimes makes the students listen to English audio like foreign sports news and commentary "by playing the mobile phone recorder". Finally, in all the teachers' opinions, listening and speaking skills should be included in the English syllabus and textbooks. That is why Teacher 8 demonstrated, "Writing that these 2 skills are urgently required, I sent a letter to Qawmi madrasa education board. But I haven't got any answer to that letter yet (with laughter)." His response indicates that there is reluctance from BEFAQ board in this regard.

On the other hand, most of the students responded that they do not practice the listening skill in English. Further, some of them are found to have no idea about this skill because they consider it merely as listening to the teacher's speech in English and understanding. However, some students appeared to acquire this skill practically. For instance, Student 3 of Madrasa 3 said, 
"Sometimes when the foreigners speak in English, I stand beside them and listen." His fellow Student 4 goes further on saying, "From their [foreigners'] conversations, I can understand some meaning. If I don't understand any words, later on, I ask my teacher about their meaning and he answers me. In this way, I try to develop the listening skill." Again, Student 2 of this madrasa "sometimes listens to English news from radio." Besides, the Student of madrasa 4 said, "Sometimes I watch cricket and football matches on TV. Then if I hear any unknown words, I ask some others about their meaning and learn them in this way." The Student of madrasa 5 also replied so. The respondents from madrasa 7 and 8 practice English listening by watching TV. Moreover, the Student of madrasa 10 responded, "Sometimes I watch some English movies and serials on the Internet. I try to understand their themes from my relatives." Only Student 3 of madrasa 9 informed that the listening skill was practiced in the previous year: "The teacher made us listen to the audio recording and asked us individually to stand up and repeat as we listened. He taught us to learn reading $A B C$ as the speakers read out in the audio.

\section{Teaching and Learning English Speaking Skill}

Teachers mostly rely on activities like pair work, drilling, question and answer, grammatical exercise, etc. for teaching speaking skills in English. For instance, Teacher 1 lets the students practice making easy and simple sentences, sometimes in the form of questioning and answering, with the new vocabulary. The students of Madrasa 2 "practice one to one English conversation"-as the teacher expressed. And "when they commit any errors during speaking practices, I instantly detect their errors and suggest them to revise the lesson and to learn it correctly", he added. His response reveals that some of them follow the text-based instructions. For example, Teacher 5 encourages the students "to say something relevant to the topic" from the textbook. However, Teacher 8 regrets that "in only one lesson of madrasa textbook there is a dialogue, whereas dialogue is available at the end of every chapter of school books". Thus, he advocates the inclusion of more dialogues in the madrasa English textbooks. Clarifying "the vocabulary meaning part by part" in the classroom, he asks "the students to practice it in pairs, in the form of roleplaying". Again, Teacher 6 encourages his students "to practice everyday conversations in pairs" and provides corrective feedback. Teacher 3 sometimes teaches "some common dialogues with their Bangla meaning" and tries to make the students practice them in the classroom. It demonstrates that the Grammar-Translation method is applied in teaching speaking skills. Teacher 9 also tends to follow this method. As he said, "Sometimes I speak English. If they don't understand, I say that this is the Bangla of that sentence." Again, the grammar-translation method is apparent in his response.

On the other hand, a few of the respondents like Teacher 4 are disinterested in teaching the speaking skill as the performance level of their students is very weak. For instance, sometimes Teacher 7 tries to "practice a speaking skill, but the students do not feel interested to speak English because they are very weak in English and fearful about the language." Teacher 10 also expressed a similar attitude-"I don't make the students practice the speaking skill in class, because they are not good at English." Meanwhile, Teacher 11 seems to face this challenge through drilling-“First, when I say something, I make the students repeat my speech individually. Then, I converse with those who are a little bit skilled so that they can overcome shyness."

On the other hand, the students do not appear to practice the English speaking skill formally to that extent. Most of them responded that sometimes they try to speak in English with their friends and relatives. As Student 3 from Madrasa 1 expressed, "When I go home, I try to speak in English with my maternal uncle." Similarly, Student 2 of Madrasa 3 practices this skill with his "friends who study at college." His expression demonstrates that the students of general education have more proficiency in English. Besides, Student 2 of Madrasa 9 learns the English speaking skill informally-"When our madrasa remains closed, I go home and sometimes practice speaking in English with my brothers and cousins who are highly educated. They teach me English." Data from such respondents indicate that very few students have the family environment of speaking in English beyond the classroom. Still, the interview with Student 4 of that madrasa reveals that in the classroom there is very limited interaction in the English language--"During the interval of classes, I practice speaking English in pair with my friends." Only Student 1 of Madrasa 8 said, "Mostly I exchange English words with my class teacher because by sharing something with him, I can know it better." Further, the Student of Madrasa 10 is acquiring this skill through imitation-"I try to speak those which the teacher explains to us in class. Again, sometimes I try to speak whatever I watch and listen from outside." But the students of Madrasa 4 and 6 do not practice speaking in English at all.

\section{Teaching and Learning English Reading Skill}

In teaching the reading skill, all the teachers translate the English passage into Bangla for the students' better understanding. In this way, they teach new vocabulary to the students.

As for the students, some of them responded that first, they learn the spelling and pronunciation of the words according to syllables. Next, almost all of them memorize the new vocabulary meaning. For example, the student of Madrasa 2 said, "While 
reading an English text if I get any unknown words, I underline them. After finishing my class, I either look them up in the dictionary or ask my teacher about their meaning. Also by seeing the guidebook, I learn the Bangla meaning of the English text." But very few among them look up the word meaning from the dictionary. Then they read the text again and again with its Bangla translation. Again, the Grammar-Translation method is disclosed here. However, one student revealed that he read the English text without translation-"I put emphasis only on reading in English, and nothing else." After that, they try to understand the questions. Regarding this, Student 2 of Madrasa 3 responded, "To read the given questions, I try to understand the vocabulary properly." Finally, those who can understand the text and the questions with meaning can write the answers to the reading comprehension themselves.

In response to the question-"How do you answer the questions to reading comprehension?"-Student 3 of Madrasa 3 said, "After reading the text carefully, looking up the word meaning, and understanding the questions well, I can find the answers from the passage and write them on my own. Therefore, I don't have to memorize them." However, those who cannot understand the text properly either ask the teacher or brilliant students for clarification or directly memorize the answers from the guidebook. As Student 3 from Madrasa 9 expressed, "I find out the answers from the passage. If I face any problem in finding the answers, I take help of the guidebook." Some other students from other madrasas also responded so. The practice of memorization is available among some students as well-"There are some answers that I need to memorize and some others I find out from the text" (Student 3, Madrasa 9). Only one student from Madrasa 5 was found to read English beyond the textbook which is helpful for developing the reading skill in English—"Besides the textbooks, I read English storybook and English newspaper. Thus, I develop the reading skill in English."

\section{Teaching and Learning English Writing Skill}

From the interview with the students it is found that outside the English classroom, most of the students practice the English writing skill merely in the form of homework to improve their hand-writing. Here, some of them practice writing from memory, and some practice creative writing. For example, the Student of Madrasa 10 revealed, "As far as possible, I try to write a letter, application, paragraph, essay, etc on my own. However, I try to memorize those topics from books about which I have no idea." In response to the question on the process of writing English composition, Student 2 of Madrasa 3 replied, "If I want to write a paragraph on any topic, for example, in the beginning, I brainstorm about that topic, like which idea will come after which one. Again, I discuss them with other students. Then I write as far as possible and correct the rest by showing the teacher." Likewise, Student 3 from the same madrasa said, "Sometimes I memorize them but I try more to write them on my own. For instance, firstly I brainstorm ideas about a topic. Then I think about vocabulary; that means, which word will follow which one so that my writing becomes correct and fine." Though the majority of the students try to develop their writing skills regularly and academically, few students practice it very rarely and personally-"Outside the classroom, I usually practice writing only during the vacations" (Student 2, Madrasa 9). On the other hand, the interviewee of Madrasa 5 expressed, "I read stories from other books and afterward I try to write them on my own without seeing the books." The student of Madrasa 10 practices similarly - "I try to compose any story of my own accord." It is remarkable that in some instances there is also mother-tongue interference in the development of writing skills. For instance, the respondent of Madrasa 7 demonstrated, "Sometimes the teacher assigns us to write some compound words with their Bangla meaning." Again, the Grammar-Translation method is manifested from this response.

The teachers' interviews reveal that the madrasa students basically face problems with capitalization, spelling, vocabulary, and grammar at the time of writing something in English. For instance, according to Teacher 2, "In many instances, the students commit errors with Capitalization in writing." From the viewpoint of Teacher 3, "The students don't know enough English vocabulary and can't make sentences in English properly." He regretted that "as they don't focus on English for its being an optional subject, generally they are not interested to buy any bilingual dictionary" to meet the crisis. Teacher 4 expressed, "They face problems with grammar as well as spelling big words." Teacher 7 also agreed to the point saying-"They don't know the grammar rules properly. Sometimes I write some topics and discuss how to write on the topics." Meanwhile, Teacher 8 tried to justify the significance of the Grammar-Translation method in resolving the students' lack of writing skill: "If I ask them to write a paragraph, firstly they cannot set its Bangla. Even if they can form an idea in Bangla, they cannot translate it into English following the grammar rules like constructing a sentence with a subject, an auxiliary verb, and a predicate." Teacher 5 too reported that the students "face problems with spelling and the use of appropriate words." Teacher 6 is concerned about their spelling: "The students mainly face the problem with spelling. So, I write the correct spelling in their notebook and ask them to write the modified word at least 3 times." Due to the same problem in Madrasa 9, the teacher suggests "the students to memorize the spelling when they memorize a paragraph." Since the same problem exists in Madrasa 10, its Teacher 1 focuses on better hand-writing; while Teacher 2 thinks of "minimizing the problem by writing the pronunciation for them beside the word." Only Teacher 1 appeared to be satisfied with the writing 
proficiency of his students: "The students' writing skill is satisfactory because they practice writing correctly in class and practice better hand-writing regularly."

On the other hand, regarding the challenges of writing in English Student 3 of Madrasa 1 said, "Usually I face problems with spelling. Sometimes I become confused about whether my writing is correct or not, especially it becomes difficult for me to make sentences in English. And the teacher shows us how to write correctly and encourages us to try to do well later on. He also assigns additional writing tasks to 5 selected weaker students every day." His response indicates that there is a lack of selfconfidence in the student in writing English but there is positive reinforcement from the teacher. Student 4 of Madrasa added, "The teacher tells us to write the correct spelling 7-10 times." Furthermore, Student 2 of Madrasa 3 faces difficulty with vocabulary use-"When I write something in English, usually I commit mistakes in using the appropriate words; that means, where to use which words. In such cases of academic writing, the teacher immediately identifies my mistakes and corrects them with clarification." Student 1 of Madrasa 8 said so as well. Thus, the teachers support them by correcting their errors through immediate feedback. However, there is a little tendency of self-correction in his response too-"I also solve the problem of spelling by looking up the vocabulary, its pronunciation, and meaning in the dictionary." Like him, Student 1 of Madrasa 9 either sees the book or consults the teacher. Exceptionally, the respondent from Madrasa 7 seemed to be concerned about the quality of his handwriting "Sometimes my handwriting becomes poor and the teacher teaches me how to write properly." Last but not the least, the student of Madrasa 10 faced the problem with the organization of the composition. In his words, "In writing something, my words may not be well organized. In that case, I ask my teacher, 'Sir, how can I write this idea in an organized way?' Then the teacher explains to me, saying-'Write it in this way'." Only 2 respondents among the students demonstrated that they faced no problem in writing something in English.

\subsubsection{Classroom Observations}

A good linguistic classroom environment can play a very important part in contributing to the development of language teaching and learning. "As language classrooms are specifically constituted to bring about learning, it is not unreasonable to collect data about what goes on there as a means of adding to our knowledge of language learning and use" (Nunan, 1992: 91). Therefore, 10 Madrasas were observed to identify the procedure of teaching and learning the English language in the classroom.

\section{Teaching the Listening Skill}

As has already been discussed, no audio-visual aids were available in any classrooms of the madrasas observed. Hence, there was no practice of listening skills in the English language.

\section{Teaching the Speaking Skills}

A great amount of negligence was found in madrasa teachers in developing the speaking ability of the students. Speaking practices were mostly confined to asking and answering questions among teachers and students. Sometimes, teachers asked questions in English and translated them into Bangla so that the students could understand them. Only one teacher was found focusing on speaking skills. He taught students how to make sentences orally with given words and practiced oral translation of new sentences. Some teachers just encouraged students to practice conversation in English among themselves, but no significant classroom practice was found for that purpose.

\section{Teaching the Reading Skill}

The most common phenomenon in teaching reading skills seen in madrasas was that the teacher asked any student to read the text aloud. While the student was reading, the teacher interrupted him by asking word meaning. When he could not answer, the teacher himself conveyed the meaning. The teacher also corrected immediately while the student committed some errors. Fluency in reading was taken into consideration at that time. During teaching reading skills, teachers were observed to translate the meaning of the texts in the first language. Some teachers explained some grammar rules while translating the text. It was also observed that the teachers asked questions based on the reading comprehension from the textbook. Sometimes, teachers made their students drill with them while reading a passage or poem aloud from the textbook. So, it is obvious that teaching and learning practices of reading skills in madrasas are mainly based on textbook-based materials and the Grammar-Translation method.

\section{Teaching the Writing Skill:}

Writing exercises basically revolved around teachers' assigning homework to students in the classroom and checking them in the following class regularly, and along with this, students copying the writings from the blackboard or whiteboard which 
were written by the teachers. In most cases, a passage or a few sentences from the textbook were selected as homework. Most of the teachers were seen to start the class by checking the assigned homework and giving immediate feedback mostly in the Bangla language. While checking homework, some teachers emphasized spelling accuracy. Some teachers gave feedback just by appreciating the good handwriting and pointing out the errors immediately, whereas some teachers were found giving marks. Besides, teachers taught different types of writing like paragraphs, essays, and letters by writing a sample on the board and explaining it. It is noteworthy that since there was no board in the English classroom of one madrasa, the teacher copied an application from the textbook to a student's notebook and discussed how to write it. This phenomenon indicates a lack of very essential classroom equipment. A few teachers taught their students how to make sentences with the given words and taught them different sentence structures.

Above all, with regard to communicative activities, the main course objective, only one teacher was found to practice brief conversational exchanges in the target language in an English classroom and this was done at the very beginning of the lesson, during the so-called 'warm-up' activity: the teacher first greeted the class, and the students answered.

\section{Conclusion \& Recommendations}

Since the Bangladesh government has recognized the highest degree of Qawmi madrasa as equivalent to a Master's degree in Arabic and Islamic Studies of general education, the Qawmi graduates would obviously apply for government and nongovernment jobs, and for that proficiency in basic English language skills is an integral requirement. Even if they want to work abroad, they need communicative competence in English. But they cannot achieve it because even though their teaching and learning reading and writing skills are satisfactory, they ignore or avoid the listening and speaking skills in the classroom and examination. As the study has uncovered, the challenges behind the phenomenon include the faulty syllabus design, limited textbook contents, and testing system, backdated language teaching method, inadequate classroom aids, and equipment, students' lack of interaction in English with teachers and fellow students inside the classroom and with people in real-life situations, their fear and anxiety of speaking in English, etc. Unless these problems are solved, the students of Qawmi madrasas can never be communicatively competent in English to meet the global and national demands. For that, firstly BEFAQ should make the English test compulsory, modify the old syllabus, update the textbook contents, incorporate the listening and speaking skills in testing and assessment, arrange teacher training for language teaching, and conduct the English exam centrally for the Qawmi madrasa students from grade I to VIII. Secondly, although the teachers cannot discard Grammar-Translation Method totally from the madrasa education system, they can combine this traditional language teaching method with any modern approaches like Communicative Language Teaching Approach and encourage students more to interact with others only in English in the EFL classroom ignoring their fear and mistakes. Thirdly, as most of the Qawmi madrasa authorities cannot provide modern technological equipment for the language classroom, the Bangladesh government's Ministry of Education should come forward to help this conservative education sector financially and pedagogically to develop the nation for international communication.

\section{Acknowledgment}

I would like to express my sincere gratitude and appreciation to my PhD supervisor Professor Dr. Shaila Sultana who helped and inspired me very much in conducting this research. My special thanks go to Md. Rafiqul Hoque, Senior Office Assistant of BEFAQ, for providing me abundant information related to my area of study.

\section{References}

[1] Ahmed, M. (2015, May 24). 1.4 m students study in 14,000 Qawmi madrasa. The Daily Prothom Alo. https://en.prothomalo.com/bangladesh/14-lakh-students-study-in-14-000-Qawmi-madrasas

[2] Alam, F. (2005). Rethinking the English curriculum of universities in Bangladesh. Spectrum, 3, 1-19.

[3] Al-Hasani, S. M. A., Ismail, A. R., Kazeemkayode, B., \& Elega, D. A. Q. (2017). Creating a practicing Muslim: A study of Qawmi madrasah in Bangladesh. British Journal of Education, Society \& Behavioural Science, 20(3), 1-9. Retrieved https://www.researchgate.net/publication/316196868_Creating_a_Practicing_Muslim_A_Study_of_Qawmi_Madrasah_in_Bangladesh DOI: $10.9734 / B J E S B S / 2017 / 30910$

[4] Asadullah, M. N., \& Chaudhury, N. (2016). To madrasas or not to madrasas: The question and correlates of enrolment in Islamic schools in Bangladesh. International Journal of Educational Development, 49, 55-69.https://doi.org/10.1016/j.ijedudev.2016.01.005

[5] Azad, M. N. H. (2017). Challenges faced by students in learning English in grades 11 and 12 in Bangladeshi madrasahs. [Masters dissertation, London Metropolitan University]. Language in India, 17(6), 214-305. Retrieved from http://www.languageinindia.com/june2017/hudaazadenglishbangadeshmadrasa.pdf

[6] Azam, M. G., \& Tatsuya, K. (2020). Understanding the secularization process through English language teaching at Qawmi madrasa in Bangladesh. Journal of International Development and Cooperation, 26(1.2), 1-13. Retrieved from https://ci.nii.ac.jp/naid/120006811216/

[7] Badrunnesha, M. (2015). Improving the quality of girls' education in madrasas in Bangladesh. Washington DC. 
[8] Barkar, A. et al. (2011). Political economy of madrassa education in Bangladesh: Genesis, growth and impact. Ramon Publishers, Dhaka, Bangladesh.

[9] Bhattacharya, S. (2006). The perspectives of madrasa education in Bangladesh. Jadavpur Journal of International Relations, 10(1), 224-234. doi: $10.1177 / 0973598406110016$

[10] Cook, V. (2001). Using the first language in the classroom. The Canadian modern Language Review, 57(3), 402-423.

[11] Farooqui, S. (2014). The struggle to teach in English: A case study in Bangladesh. Journal of Education and Human Development, 3(2), 441457. Retrieved from http://jedsnet.com/vol-3-no-2-june-2014-abstract-25-jehd

[12] Hoque, M. E. (2008). English language teaching and learning at the Alim level in the madrashas in Bangladesh: Problems and possible solutions. [M. Phil's diss, Department of English, Jahangirnagar University, Bangladesh]. Retrieved from https://www.scribd.com/doc/28681752/English-Language-Teaching-and-Learning-in-Bangladesh\#scribd

[13] Hussain, A. A. (2018). State, Qawmi madrasas and children in Bangladesh: From a social protection perspective. [Masters dissertation, International Institute of Social Studies, Netherlands].

[14] Junias, R. (2009). Factors affecting the teaching of English reading skills in a second language of grade 3 learners. [Master's thesis, University of South Africa].

[15] Krarzia, N. (2013). Designing a syllabus for ESP learners: The case of 2nd year commercial sciences' students at the University of Constantine. [Master's thesis, University of Constantine 1, Algeria].

[16] Krashen, S. (1981). Second language acquisition and second language learning. Oxford: Pergamon Press.

[17] McDonough, J., \& McDonough, S. (1997). Research methods for English language teachers. London: Arnold.

[18] Merriam, S. B. (1998). Qualitative research and case study applications in education (2nded.). San Francisco, Ca: Jossey-Bass Publishers.

[19] Nguyen, T. H. (2015). English teaching and learning in Ho Chi Minh City University of Technology (HUTECH), Vietnam [Doctoral dissertation, RMIT University].

[20] Nunan, D. (1992). Research methods in language learning. Cambridge: Cambridge University Press.

[21] Richards, J. C., \& Rodgers, T. S. (1982a). Method: Approach, design, and procedure. TESOL Quarterly, 16(2), 153468.

[22] Richards, J. C., \& Rodgers, T. S. (2001b). Approaches and methods in language teaching ( $2^{\text {nd }}$ ed.). Cambridge: Cambridge University Press.

[23] Richards, J. C., \& Schmidt, R. (2002). Longman dictionary of language teaching and applied linguistics. Pearson Education Limited. p.231.

[24] Ruman, M. A. K., \& Bhuiyan, M. A. (2015). Ebtedayee English syllabus under BEFAQ: An evaluation. Bangladesh Research Foundation Journal, $4(1), 14-30$

[25] Spada, N. (2019). Classroom observation research. In J. Schwieter \& A. Benati (Eds.), The Cambridge handbook of language learning (Cambridge Handbooks in Language and Linguistics, pp. 186-207). Cambridge: Cambridge University Press. doi:10.1017/9781108333603.009

[26] Xiao, H., \& Petraki, E. (2007). An investigation of Chinese students' difficulties in intercultural communication and its role in ELT. Journal of Intercultural Communication, 13. Retrieved from http://www.immi.se/intercultural 